\title{
Portfolio Management and Investment Strategy of Institutional Investor: An Analysis in Indian Capital Market
}

\author{
Shivani Tyagi, Manjula Shastri
}

\begin{abstract}
The purpose of current study is to examine the most preferred investment option among institutional investor in India and analysis the factors which impact their investment strategy in India. The study also attempts to better understand the impact of certain demographic factors such as age, area of operation, type of operation, asset under management, experience and qualification on the behaviour of institutional investor in India .A semi structured questionnaire was used to obtain a total of 30 valid responses was collected from January 2019 to March 2019. Cronbach alpha test and normality test was used to check reliability and consistency in the responses. Descriptive Analysis was done for various variables. Result was presented in the tabular form.
\end{abstract}

Key Words: Institutional Investors, Preference, Investment Strategy, India.

\section{INTRODUCTION}

Investment in different areas like equity, real estate, mutual fund is very risk (Fachrudin and Fachrudin, 2015). Analysis of all the sectors and making an investment in the particular sector is very tedious and risky. To mitigate the risk involved in a particular investment, investor takes the help of diversification. They invest their money in different investment options that are not known to each other and minimize the risk of investment. Thus the investor builds up a portfolio of investment which has a minimum risk and maximum returns (Johannes 2017). Through this paper, we examine the most preferred investment option of institutional investor in India and analysed the factors which impact the investment strategies of Institutional Investor in India. Institutional investors are the people who make an investment on the behalf of the other people in the different assets .They have a considerable impact on the market condition. The size of the institutional investors is growing day by day (Joseph and Varghese ,2017). They have the professional knowledge, therefore they are considered best for the Portfolio Management .There are many categories of institutional investor such as banks, endowments funds ,hedge funds, insurance companies, mutual funds, pension funds, sovereign wealth funds, unit trusts and unit investment trusts (Nielsen 2008).

Revised Manuscript Received on July 25, 2019

Shivani Tyagi,

UGC NET JRF QUAILIFED ,Senior Research Fellow, Amity University .Noida .Academic

Manjula Shastri,

Associate Professor .Amity University .Noida .Academic Area: Accounting and Finance. Publication:20.
According to Luo and Wang (2002), as intermediaries between individual investors and firms, institutional investors make for an important source of capital in financial markets .To be precise, it can be said that institutional investor trade in such a large share of investment assets that it automatically qualifies for lower commission (Isaksson \& Celik 2014).Based on the investment horizon, institutional investor are broadly segregated into two types - transient and long term (Nielsen 2008). While the long term investors mitigate the process of aggressive earning management among firms that use accruals for meeting earnings targets, the transient investors are not systematically associated with aggressive earnings management (Bushee 1998).Rather, they work in association with firms that can manage earnings to meet or beat their earrings benchmarks (Koh 2007). According to Hutchinson et al. (2015), corporate governance has an important effect on the size of institutional investment also. A positive association between risk and performance depends on the type and size of institutional investment. Two different types of institutional investors are identified by Hutchinson et al. (2015); active investors and passive investors .This difference is primarily determined by the existence of important potential business relationship between the firm and its institutional investor (Koh2007).Based on this broader categorization, it can be said that the common types of institutional investors have certain objectives and methods for better financial performance.

According to Bushee et al. (2014), not all institutional investors have the same investment objectives or methods for better financial performance. Some institutional investors are constrained by trusting beneficiaries or effected by political concerns (Bushee et al .2014) .Understanding the heterogeneous preferences of institutional investors is increasingly important, given the recent legislative attempts to increase shareholder oversight of boards of directors and executive compensation (Luo 2002) .The basic method employed by institutional investors is that they pool funds on behalf of enterprises that need money for meeting their financial targets or beating their financial benchmarks (Bushee et al .2014). Grinblatt \& Keloharju ( 2000) argue that in order to achieve financial targets the institutional investors need to examine the preconditions of investment by evaluating the business and investment climate, macroeconomic conditions and other such factors .According to Bushee et al.(2014), the basic objectives of investments such as finance and tax regulations are addressed 
after the implementation of savings, mobilizing to address the long term saving needs of various firms .According to Luo (2002) investment strategies are affected by home country environment parameters, including economic growth, perceived institutional hardship, competitive pressure, and by operational characteristics , including inward internationalization, innovation orientation and business development stage. The negative association between risk and performance is moderated by governance quality while large non- business institutional ownership moderates the negative association by acting as a substitute monitoring mechanism when governance is low (Hutchinson et al. (2015) .

\section{LITERATURE REVIEW}

According to the report of (OECD 2011)in India, the role of institutional investors such as banks, insurance companies and monetary funds are to typically act as financial intermediaries. This category also includes other financial institutions such as investment banks, insurance companies, broker-dealers, mutual funds and pension funds(Sarkar\&Sarkar 2000).However, the ownership structure of companies varies widely across jurisdictions and with it the potential role and responsibilities of institutional investors(Nicole Choi et al.2017.Since, institutional investors are large funds that invest money in securities, such as, pension funds, hedge funds and insurance companies, they play an important role because they have a massive amount of money and they can use this money for immediate investments(OECD 2011). Given the current low interest rate environment and weak economic growth prospects in many Organisation for Economic Co-operation and Development (OECD) countries, the role of institutional investors are increasingly becoming inflation-linked, in search of assets that can deliver steady returns(OECD 2011).Private agents and policy makers need to improve the corporate governance outcomes of institutional investors' behaviour because institutional investors can play an important role both in jurisdictions characterised by separate or concentrated proprietorship, if their role is facilitated by private and or public policy action(Nicole Choi et al.2017).

Sudalaimuthu and Senthil Kumar (2008), in their research talks about the financial performance of mutual fund investor in relation with the project preference and selection .An significant factor in the fame of a marketing strategy is the strength to fulfil investor's assumption .Ravi Vyas and Suresh C Moonat (2012) implement a study on the viewpoint and performance of mutual fund investors. The study was accomplished to interpret the investor's perception about different investment alternatives, by investors at Indore with a sample size of 500 respondents out of which 363 respondents were investing in mutual funds, and these 363 respondent's data was evaluate to come out with result. A structured questionnaire was used to compile the data during personal interview .To explain the nature of holding by the investors, chi-square test was adopted onward with the computation of median and mode .After analysis of data, it was analysed that Gold was the most favoured investment avenue followed by bank deposits .Mutual fund investment have average score in parameters like safety, liquidity, reliability and tax benefits. Majority of the investors were familiar about the risk involved with mutual funds .Direct equity investment was least most preferred investment alternative. Priyanka Sharma and Payal Agarwal (February 2015 investigate preference of mutual funds investors and Performance Evaluation of the preferred schemes by the investors. The survey tested 50 professional investor of Udaipur city, and the major findings confess the buying performance of mutual funds investors, expert that investors rely on while making the investment and preferred mode to invest in mutual funds market.

\section{RESEARCH METHDOLOGY}

\section{A. Research Objective:}

- To find out the most preferred investment options among institutional investors in India.

- To study the factors influence investment choice of institutional investor.

- To study the factors impact investment strategies of institutional investors in India.

B. Research Philosophy:The present study makes utilization of the positivist research philosophy which is based on natural phenomenon and their properties and relationship.

C. Research Design: The present study make utilization of Descriptive research design as it helps in describing the preference of institutional investor in India.

D. Research Approach: The present study adopted quantitative research approach since the outcomes was obtained in numbers.

E. Type of Data: The present study adopted primary source of data that involves the gathering of first hand data through application of research instruments. Based on random sampling, 30 participants participated in the survey. Primary data was collected from fund manager, investment bankers of Domestic and foreign Institutional Investor in India. Independent respondent was also contacted who either are working as part of a consulting firm or working on freelancing basis. 


\section{IV.DATA ANALYSIS AND INTERPRETATION}

Table1: The following statistics were observed for the respondents

\begin{tabular}{|c|c|c|c|c|c|c|}
\hline $\begin{array}{l}\text { Serial } \\
\text { No }\end{array}$ & Background of th & respondent & Frequency & Percent & $\begin{array}{l}\text { Valid } \\
\text { Percent }\end{array}$ & $\begin{array}{l}\text { Cumulative } \\
\text { Percent }\end{array}$ \\
\hline \multirow[t]{3}{*}{1} & \multirow{3}{*}{$\begin{array}{l}\text { Type of } \\
\text { Operation }\end{array}$} & FII & 12 & 40 & 40 & 40 \\
\hline & & DII & 18 & 60 & 60 & 100 \\
\hline & & Total & 30 & 100 & 100 & \\
\hline \multirow[t]{4}{*}{2} & \multirow{4}{*}{$\begin{array}{l}\text { Area of } \\
\text { Operation }\end{array}$} & Equity & 6 & 20 & 20 & 20 \\
\hline & & Debt & 4 & 13.33 & 13.33 & 33.33 \\
\hline & & Mixed & 20 & 66.66 & 66.66 & 100 \\
\hline & & Total & 30 & 100 & 100 & \\
\hline \multirow[t]{5}{*}{3} & \multirow[t]{5}{*}{ Respondent Age } & 20-30 Years & 18 & 60 & 60 & 60 \\
\hline & & 31-40 Years & 6 & 20 & 20 & 80 \\
\hline & & 41-50 Years & 3 & 10 & 10 & 90 \\
\hline & & 51-60 Years & 3 & 10 & 10 & 100 \\
\hline & & Total & 30 & 100 & & \\
\hline \multirow[t]{5}{*}{5.} & \multirow{5}{*}{$\begin{array}{l}\text { Respondent } \\
\text { Qualification }\end{array}$} & Graduate & 9 & 30 & 30 & 30 \\
\hline & & $\begin{array}{l}\text { Post } \\
\text { Graduate }\end{array}$ & 15 & 50 & 50 & 80 \\
\hline & & Doctorate & 3 & 10 & 10 & 90 \\
\hline & & Professional & 3 & 10 & 10 & 100 \\
\hline & & Total & 30 & 100 & 100 & \\
\hline \multirow[t]{5}{*}{6.} & \multirow[t]{5}{*}{$\begin{array}{l}\text { Asset Under } \\
\text { Management }\end{array}$} & $\begin{array}{l}\text { Less than } \\
1000 \text { crore }\end{array}$ & 18 & 60 & 60 & 60 \\
\hline & & $\begin{array}{l}1000-5000 \\
\text { crore }\end{array}$ & 9 & 30 & 30 & 90 \\
\hline & & $\begin{array}{l}20000- \\
50000 \text { crore }\end{array}$ & 2 & 6.66 & 6.66 & 96.66 \\
\hline & & $\begin{array}{l}\text { Above } 50000 \\
\text { crore }\end{array}$ & 1 & 3.33 & 3.33 & 100 \\
\hline & & Total & 30 & 100 & 100 & \\
\hline \multirow[t]{6}{*}{7.} & \multirow[t]{6}{*}{$\begin{array}{l}\text { Experience of } \\
\text { Operation }\end{array}$} & $\begin{array}{l}\text { Less than } 5 \\
\text { Years }\end{array}$ & 12 & 40 & 40 & 40 \\
\hline & & 5-8 Years & 9 & 30 & 30 & 70 \\
\hline & & 8-12 Years & 6 & 20 & 20 & 90 \\
\hline & & 12-18 Years & 3 & 10 & 10 & 100 \\
\hline & & 18-25 Years & - & - & - & \\
\hline & & Total & 30 & 100 & 100 & \\
\hline
\end{tabular}

Source: Primary Data

Total no. of Respondent: 30

Interpretation:Among the respondents, $40 \%$ belonged to the foreign institutional investor while $60 \%$ were related to the domestic institutional investor. For the area of operations, $20 \%$ of the investor's profile was in only equity investments, $13.33 \%$ investor's profile was in only debt investments, while $66.66 \%$ of the investor's profile was in both equity and debt investments. For the assets under management, it was found that $60 \%$ of the investor's firm was operating at less than 1000 Crore for assets, 30\% were between 1000-5000 Crore, $6.66 \%$ were 20000-50000 Crore and 3.33\% were above 50000 crore. From the experience point of view, $40 \%$ of the respondents were having an experience of less than 5 years, $30 \%$ of the respondents were having an experience of between 5-8 years, $20 \%$ were having an experience of 8 to 12 years, and $10 \%$ were having experience between 12-18 years. From the educational qualification point of view, $30 \%$ of the respondents were graduate, $50 \%$ of the respondents were Post-graduate, $10 \%$ were doctorate, and $10 \%$ were professionals. From the age point of view, $60 \%$ of the respondents were having age between 20-30 years, $20 \%$ of the respondents were having age between $31-40$ years, $10 \%$ were having age between $41-50$ years, and 10 $\%$ were having age between 51-60 years.

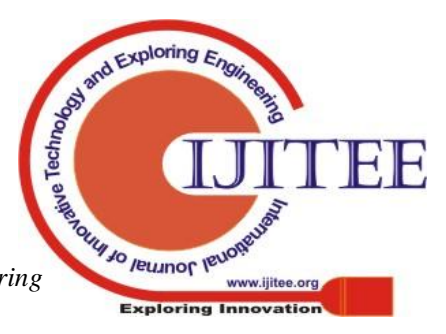




\section{Reliability Test:}

The reliability of the each component and all the variables obtain tested using Cronbach Alpha test (Bland and Altman, 1997) .It is the largely commonly used test for analyse the reliability of the responses collected for different types of likert scale based questions .A value of over 0.7 is widely acceptable .

\section{Reliability Statistics}

\section{KMO and Bartlett's Test:}

Table 3:

\begin{tabular}{|l|l|c|}
\hline \multicolumn{2}{|c|}{ KMO and Bartlett's Test } \\
\hline Kaiser-Meyer -Olkin Measure of Sampling Adequacy & .721 \\
\hline Bartlett's Test of Sphericity & Approx. Chi-Square & 782.32 \\
\cline { 2 - 3 } & Df & 129 \\
\cline { 2 - 3 } & Sig & .003 \\
\hline
\end{tabular}

Source: Primary Data

Interpretation: The above table talks the KMO and Bartlett's test .It has been observed that the sampling adequacy value wass. 721 and the Chi-square value were 782.32 which are statistically significant at $95 \%$ confidence level. This
Table 2

\begin{tabular}{|l|l|}
\begin{tabular}{|l|l|}
\hline $\begin{array}{l}\text { Cronbach's } \\
\text { Alpha }\end{array}$ & $\mathrm{N}$ of Items \\
\hline .892 & 35 \\
\hline
\end{tabular} \\
Source: Primary Data
\end{tabular}

Interpretation: From the above table, it was noticed that reliability of all the 35 factors taken together was. 892 in which all the 30 responses were examined. Thus, it can be achieve that individual item are reliable.

Table No 4:

Factors determine the success of Institutional Investors:

\begin{tabular}{|c|c|c|c|c|c|c|c|}
\hline S.no & Factor & $\begin{array}{l}\text { Strongly } \\
\text { Agree }\end{array}$ & Agree & Neutral & Disagree & $\begin{array}{l}\text { Strongly } \\
\text { Disagree }\end{array}$ & Total \\
\hline \multirow[t]{2}{*}{1} & \multirow{2}{*}{$\begin{array}{l}\text { Quality of } \\
\text { Service }\end{array}$} & 11 & 13 & 4 & 2 & \multirow[t]{2}{*}{-} & \multirow[t]{2}{*}{30} \\
\hline & & -36.66 & -43.33 & -13.33 & -6.66 & & \\
\hline \multirow[t]{2}{*}{2} & \multirow{2}{*}{$\begin{array}{l}\text { Suitability } \\
\text { of Product }\end{array}$} & 11 & 15 & 2 & 2 & \multirow[t]{2}{*}{ - } & \multirow[t]{2}{*}{30} \\
\hline & & -36.66 & -50 & -6.66 & -6.66 & & \\
\hline \multirow[t]{2}{*}{3} & \multirow[t]{2}{*}{ Research } & $\overline{9}$ & 10 & 8 & 3 & \multirow[t]{2}{*}{ - } & \multirow[t]{2}{*}{30} \\
\hline & & -30 & -33.33 & -26.66 & -10 & & \\
\hline \multirow[t]{2}{*}{4} & \multirow{2}{*}{$\begin{array}{l}\text { Risk } \\
\text { Orientation }\end{array}$} & 7 & 6 & 10 & 6 & 1 & \multirow[t]{2}{*}{30} \\
\hline & & -23.33 & -20 & -33.33 & -20 & -3.33 & \\
\hline \multirow[t]{3}{*}{5} & No. of & 12 & 5 & 9 & 4 & - & $\overline{30}$ \\
\hline & Investor & & & & & & \\
\hline & Centres & -40 & -16.66 & -30 & -13.33 & & \\
\hline
\end{tabular}

Source: Primary Data

Interpretation: The above table shows that No. of investor services centers $(40 \%)$, quality of service $(36.66 \%)$ and signifies that the thirty-five items determine the investment choice of institutional investor and iscapable in illustrating the most preferred investment avenue among institutional investor in India suitability of product $(36.66 \%)$ as important factors determinants for the success of institutional investment. 
Table: 4.

Analysis of Table: 4

\begin{tabular}{|l|l|l|l|}
\hline S.no & Factor & Mean Score & Rank \\
\hline 1. & $\begin{array}{l}\text { Quality of } \\
\text { Service }\end{array}$ & 4.1 & 2 \\
\hline 2. & $\begin{array}{l}\text { Suitability of } \\
\text { Product }\end{array}$ & 4.16 & 1 \\
\hline 3. & Research & 3.83 & 3 \\
\hline 4. & $\begin{array}{l}\text { Risk } \\
\text { Orientation }\end{array}$ & 3.4 & 4 \\
\hline 5. & $\begin{array}{l}\text { No. of } \\
\text { Investor } \\
\text { Service } \\
\text { Centres }\end{array}$ & 3.833 & 3 \\
\hline
\end{tabular}

Source: Primary Data

Interpretation: From the ranking method of the mean score success of institutional investment. Next important factors in the above table 2.1, five factors have been identified for which ranked at number 3 are research and No.of investor determine the success of institutional investor. Among the service centres and research. Other important factor identified various factors suitability of product and quality of service are according to survey is risk orientation.

identified as most important factors determinants for the

Table 5:

Factors which are important in the choice of an investment scheme by institutional investor

\begin{tabular}{|c|c|c|c|c|c|c|c|}
\hline S.no & Factor & $\begin{array}{l}\text { Strongly } \\
\text { Agree }\end{array}$ & Agree & Neutral & Disagree & $\begin{array}{l}\text { Strongly } \\
\text { Disagree }\end{array}$ & Total \\
\hline 1. & $\begin{array}{l}\text { Capital } \\
\text { Appreciation }\end{array}$ & $\begin{array}{l}12 \\
(40)\end{array}$ & $\begin{array}{l}14 \\
(46.66)\end{array}$ & $\begin{array}{l}2 \\
(6.66)\end{array}$ & $\begin{array}{l}2 \\
(6.66)\end{array}$ & - & 30 \\
\hline 2. & $\begin{array}{l}\text { Objective of } \\
\text { scheme }\end{array}$ & $\begin{array}{l}8 \\
(26.66)\end{array}$ & $\begin{array}{l}15 \\
(50)\end{array}$ & $\begin{array}{l}7 \\
(23.33)\end{array}$ & - & - & 30 \\
\hline 3. & ROI & $\begin{array}{l}19 \\
(63.33)\end{array}$ & $\begin{array}{l}8 \\
(26.66)\end{array}$ & $\begin{array}{l}2 \\
(6.66)\end{array}$ & - & $\begin{array}{l}1 \\
(3.33)\end{array}$ & 30 \\
\hline 4. & Tax Benefit & $\begin{array}{l}4 \\
(13.33)\end{array}$ & $\begin{array}{l}18 \\
(60)\end{array}$ & $\begin{array}{l}4 \\
(13.33)\end{array}$ & $\begin{array}{l}2 \\
(6.66)\end{array}$ & $\begin{array}{l}2 \\
(6.66)\end{array}$ & 30 \\
\hline 5. & Liquidity & $\begin{array}{l}8 \\
(26.66)\end{array}$ & $\begin{array}{l}15 \\
(50)\end{array}$ & $\begin{array}{l}4 \\
(13.33)\end{array}$ & $\begin{array}{l}3 \\
(10)\end{array}$ & - & 30 \\
\hline 6. & Safety & $\begin{array}{l}12 \\
(40)\end{array}$ & $\begin{array}{l}10 \\
(33.33)\end{array}$ & $\begin{array}{l}7 \\
(23.33)\end{array}$ & $\begin{array}{l}1 \\
(3.33)\end{array}$ & - & 30 \\
\hline 7. & Loan facility & $\begin{array}{l}8 \\
(26.66)\end{array}$ & $\begin{array}{l}11 \\
(36.66)\end{array}$ & $\begin{array}{l}7 \\
(23.33)\end{array}$ & $\begin{array}{l}3 \\
(10)\end{array}$ & $\begin{array}{l}1 \\
(3.33)\end{array}$ & 30 \\
\hline 8. & $\begin{array}{l}\text { Convenience } \\
\text { of } \\
\text { reinvestment }\end{array}$ & $\begin{array}{l}7 \\
(23.33)\end{array}$ & $\begin{array}{l}10 \\
(33.33)\end{array}$ & $\begin{array}{l}9 \\
(30)\end{array}$ & $\begin{array}{l}4 \\
(13.33)\end{array}$ & - & 30 \\
\hline 9. & $\begin{array}{l}\text { Background } \\
\text { of Investors }\end{array}$ & $\begin{array}{l}4 \\
(13.33)\end{array}$ & $\begin{array}{l}17 \\
(56.66)\end{array}$ & $\begin{array}{l}7 \\
(23.33)\end{array}$ & $\begin{array}{l}2 \\
(6.66)\end{array}$ & - & 30 \\
\hline 10. & $\begin{array}{l}\text { Early bird } \\
\text { incentive }\end{array}$ & $\begin{array}{l}4 \\
(13.33)\end{array}$ & $\begin{array}{l}9 \\
(30)\end{array}$ & $\begin{array}{l}10 \\
(33.33)\end{array}$ & $\begin{array}{l}5 \\
(16.66)\end{array}$ & $\begin{array}{l}2 \\
(6.66)\end{array}$ & 30 \\
\hline
\end{tabular}

Source: Primary Data

Interpretation: The above table indicates that majority of the respondents showed their acceptance regarding all the factors which are important in the choice of an investment scheme by institutional investor. Highest percentages i.e.
63.33 percent of the respondents are strongly agreed with ROI factor, whereas only 3.33 percent 
was disagree with this factor.40 percent of the respondents are strongly agreed with capital appreciation and safety factors, whereas capital appreciation (6.66 percent ), safety (3.33 percent ) are strongly disagreed .Only 13.33 percent respondents strongly agreed with early bird incentive, whereas 2 perecent are strong disagree with this factor. 60 percent of the respondent are agreed with tax benefit, whereas only 2 percent are disagree with this factor .50 percent of the respondent strongly agree with objective of schemes and liquidity factors, whereas 3 perecent respondent are disagreed with liquidity factor .56 .66 percent respondent are agreed with background of the investors factors, whereas 2 percent investor are disagreed with this factor .More than $30 \%$ the respondent are agreed with convenience of reinvestment and loan facility factors ,whereas 3.33 percent respondent are disagree with the loan facility factors .

\section{Table 5.1}

\section{Analysis of Table 5}

\begin{tabular}{|l|l|l|l|}
\hline S.no & Factors & $\begin{array}{l}\text { Mean } \\
\text { Score }\end{array}$ & Rank \\
\hline 1. & $\begin{array}{l}\text { Capital } \\
\text { Appreciation }\end{array}$ & 4.2 & 3 \\
\hline 2. & Objective of & 4.5 & 1 \\
\hline
\end{tabular}

\begin{tabular}{|l|l|l|l|}
\hline & Scheme & & \\
\hline 3. & ROI & 4.4 & 2 \\
\hline 4. & Tax Benefit & 3.6 & 8 \\
\hline 5. & Liquidity & 3.9 & 5 \\
\hline 6. & Safety & 4.1 & 4 \\
\hline 7. & Loan facility & 3.73 & 7 \\
\hline 8. & $\begin{array}{l}\text { Convenience } \\
\text { of } \\
\text { reinvestment }\end{array}$ & 3.6 & 8 \\
\hline 9. & $\begin{array}{l}\text { Background } \\
\text { of Investors }\end{array}$ & 3.76 & 6 \\
\hline 10. & $\begin{array}{l}\text { Early bird } \\
\text { incentive }\end{array}$ & 3.2 & 9 \\
\hline
\end{tabular}

Source: Primary Data

\section{Interpretation:}

From the ranking method of the mean score in the above table ten factors have been identified which are important in the choice of investment scheme by institutional investor .Among the various factors objective of scheme and ROI are identified most important factor .Next two important factors which ranked at number 3 and 4 are Capital Appreciation and Safety .Others important factors identified according to the survey are Liquidity ,Background of investors , Loan facility, Convenience of reinvestment and Early bird incentive.

Table 6:

Following are most preferred investment options in India which are managed by Institutional Investors.

\begin{tabular}{|c|c|c|c|c|c|c|}
\hline Factors & $\begin{array}{l}\text { Very } \\
\text { Important }\end{array}$ & Important & Neutral & $\begin{array}{l}\text { Not } \\
\text { Important }\end{array}$ & $\begin{array}{l}\text { Not at all } \\
\text { Important }\end{array}$ & Total \\
\hline $\begin{array}{l}\text { Fixed } \\
\text { Deposits }\end{array}$ & $\begin{array}{l}7 \\
(23.33)\end{array}$ & $\begin{array}{l}11 \\
(36.66)\end{array}$ & $\begin{array}{l}4 \\
(13.33)\end{array}$ & $\begin{array}{l}6 \\
(20)\end{array}$ & $\begin{array}{l}2 \\
(6.66)\end{array}$ & 30 \\
\hline Insurance & $\begin{array}{l}4 \\
(13.33)\end{array}$ & $\begin{array}{l}17 \\
(56.66)\end{array}$ & $\begin{array}{l}7 \\
(23.33)\end{array}$ & $\begin{array}{l}2 \\
(6.66)\end{array}$ & - & 30 \\
\hline $\begin{array}{l}\text { National } \\
\text { Saving } \\
\text { Certificate }\end{array}$ & $\begin{array}{l}4 \\
(13.33)\end{array}$ & $\begin{array}{l}14 \\
(46.66)\end{array}$ & $\begin{array}{l}8 \\
(26.66)\end{array}$ & $\begin{array}{l}2 \\
(6.66)\end{array}$ & $\begin{array}{l}2 \\
(6.66)\end{array}$ & 30 \\
\hline Gold/e-gold & $\begin{array}{l}6 \\
(20)\end{array}$ & $\begin{array}{l}15 \\
(50)\end{array}$ & $\begin{array}{l}5 \\
(16.66)\end{array}$ & $\begin{array}{l}1 \\
(3.33)\end{array}$ & $\begin{array}{l}3 \\
(10)\end{array}$ & 30 \\
\hline Bonds & $\begin{array}{l}3 \\
(10)\end{array}$ & $\begin{array}{l}22 \\
(73.33)\end{array}$ & $\begin{array}{l}4 \\
(13.33)\end{array}$ & - & $\begin{array}{l}1 \\
(3.33)\end{array}$ & 30 \\
\hline $\begin{array}{l}\text { Public } \\
\text { Provident } \\
\text { Funds }\end{array}$ & $\begin{array}{l}5 \\
(16.66)\end{array}$ & $\begin{array}{l}16 \\
(53.33)\end{array}$ & $\begin{array}{l}7 \\
(23.33)\end{array}$ & - & $\begin{array}{l}2 \\
(6.66)\end{array}$ & 30 \\
\hline Real Estate & $\begin{array}{l}4 \\
(13.33)\end{array}$ & $\begin{array}{l}18 \\
(60)\end{array}$ & $\begin{array}{l}5 \\
(16.66)\end{array}$ & $\begin{array}{l}3 \\
(10)\end{array}$ & - & 30 \\
\hline $\begin{array}{l}\text { Mutual } \\
\text { Funds }\end{array}$ & $\begin{array}{l}12 \\
(40) \\
(\end{array}$ & $\begin{array}{l}13 \\
(43.33)\end{array}$ & $\begin{array}{l}4 \\
(13.33)\end{array}$ & $\begin{array}{l}1 \\
(3.33)\end{array}$ & - & 30 \\
\hline Shares & $\begin{array}{l}15 \\
(50)\end{array}$ & $\begin{array}{l}11 \\
(36.66)\end{array}$ & $\begin{array}{l}4 \\
(13.33)\end{array}$ & - & - & 30 \\
\hline Commodities & $\begin{array}{l}10 \\
(33.33)\end{array}$ & $\begin{array}{l}12 \\
(40)\end{array}$ & $\begin{array}{l}7 \\
(23.33)\end{array}$ & $\begin{array}{l}1 \\
(3.33)\end{array}$ & - & 30 \\
\hline
\end{tabular}


Interpretation:One of the main objective of the current study is to find out the most preferred investment options among institutional investor in India .To achieve this objective, various institutional investor have been asked about preferred investment options. The finding are given in above table 4 .It was found that shares( 50 percent ) and mutual funds ( 40) are most preferred investment options among institutional investors, whereas they least preferred investment options are bonds (3.33 percent ) followed by Public Provident Fund ( 6.66) and National Saving Certificate ( 6.66) .

Table 6.1Analyse of Table: 6

\begin{tabular}{|l|l|l|l|}
\hline S.no & Factors & Mean Score & Rank \\
\hline 1. & Fixed Deposits & 4.16 & 3 \\
\hline 2. & Insurance & 3.76 & 7 \\
\hline 3. & $\begin{array}{l}\text { National } \\
\text { Saving } \\
\text { Certificate }\end{array}$ & 3.53 & 9 \\
\hline 4. & Gold/e-gold & 3.83 & 6 \\
\hline 5. & Bonds & 3.86 & 5 \\
\hline 6. & $\begin{array}{l}\text { Public } \\
\text { Provident } \\
\text { Funds }\end{array}$ & 3.73 & 8 \\
\hline
\end{tabular}

\begin{tabular}{|l|l|l|l|}
\hline 7. & Real Estate & 3.76 & 7 \\
\hline 8. & Mutual Funds & 4.2 & 2 \\
\hline 9. & Shares & 4.36 & 1 \\
\hline 10. & Commodities & 4.03 & 4 \\
\hline
\end{tabular}

Source: Primary Data

Interpretation:The above table shows the mean score and rank assign to each financial asset according to the survey .Investors preferred share in the first instance with the rank of one .The second rank was towards Mutual Fund and the third place was for Fixed Deposits. Commodities were the fourth preferred financial asset. Bonds and Gold/e-gold was on fifth and sixth place respectively. Real Estate and Insurance have got the seventh rank .Public Provident Funds and National Saving Certificates are least preferred Investment options.

Table: 7

Factors which impact the investment strategies of Institutional Investor in India:

\begin{tabular}{|c|c|c|c|c|c|c|}
\hline Factor & $\begin{array}{c}\text { Strongly } \\
\text { Agree }\end{array}$ & Agree & Neutral & Disagree & $\begin{array}{l}\text { Strongly } \\
\text { Disagree }\end{array}$ & Total \\
\hline $\begin{array}{l}\text { Business } \\
\text { climate }\end{array}$ & $\begin{array}{l}13 \\
(43.33)\end{array}$ & $\begin{array}{l}14 \\
(46.66)\end{array}$ & $\begin{array}{l}3 \\
(10)\end{array}$ & - & - & 30 \\
\hline $\begin{array}{l}\text { Political } \\
\text { stability }\end{array}$ & $\begin{array}{l}15 \\
(50)\end{array}$ & $\begin{array}{l}12 \\
(40)\end{array}$ & $\begin{array}{l}2 \\
(6.66)\end{array}$ & - & $\begin{array}{l}1 \\
(3.33)\end{array}$ & 30 \\
\hline Labour laws & $\begin{array}{l}2 \\
(6.66) \\
\end{array}$ & $\begin{array}{l}4 \\
(13.33)\end{array}$ & $\begin{array}{l}16 \\
(53.33)\end{array}$ & $\begin{array}{l}5 \\
(16.66)\end{array}$ & $\begin{array}{l}3 \\
(10)\end{array}$ & 30 \\
\hline $\begin{array}{l}\text { Skilled } \\
\text { labour }\end{array}$ & $\begin{array}{l}10 \\
(33.33)\end{array}$ & $\begin{array}{l}18 \\
(60)\end{array}$ & $\begin{array}{l}2 \\
(6.66)\end{array}$ & - & - & 30 \\
\hline $\begin{array}{l}\text { India's } \\
\text { image }\end{array}$ & $\begin{array}{l}10 \\
(33.33)\end{array}$ & $\begin{array}{l}17 \\
(56.66)\end{array}$ & $\begin{array}{l}3 \\
(10)\end{array}$ & - & - & 30 \\
\hline Infrastructure & $\begin{array}{l}11 \\
(36.66)\end{array}$ & $\begin{array}{l}13 \\
(43.33) \mathrm{s}\end{array}$ & $\begin{array}{l}6 \\
(20) \\
\end{array}$ & - & - & 30 \\
\hline $\begin{array}{l}\text { Economic } \\
\text { reforms }\end{array}$ & $\begin{array}{l}7 \\
(23.33)\end{array}$ & $\begin{array}{l}15 \\
(50)\end{array}$ & $\begin{array}{l}7 \\
(23.33)\end{array}$ & $\begin{array}{l}1 \\
(3.33)\end{array}$ & - & 30 \\
\hline Entry options & $\begin{array}{l}18 \\
(60)\end{array}$ & $\begin{array}{l}11 \\
(36.66)\end{array}$ & $\begin{array}{l}1 \\
(3.33)\end{array}$ & - & - & 30 \\
\hline Exit options & $\begin{array}{l}18 \\
(60) \\
\end{array}$ & $\begin{array}{l}11 \\
(36.66)\end{array}$ & $\begin{array}{l}1 \\
(3.33)\end{array}$ & - & - & 30 \\
\hline $\begin{array}{l}\text { Specific } \\
\text { sector's } \\
\text { performance }\end{array}$ & $\begin{array}{l}12 \\
(40)\end{array}$ & $\begin{array}{l}16 \\
(53.33)\end{array}$ & $\begin{array}{l}2 \\
(6.66)\end{array}$ & - & - & 30 \\
\hline
\end{tabular}

Source: Primary Data

Interpretation: The above table 5 indicates that the majority of the respondents showed their acceptance regarding all the factors which impact the investment strategy of Institutional investor in India. 60 perecent of the respondent are strongly agreed with entry and exit options factors.50 perecent of the respondent are strongly agreed with political stability factors, whereas only $3.33 \%$ are strongly disagree with this factor.56.66 percent respondent supported India's image factor .50 percent of the respondent supported the economic reforms factor, whereas only 3.33 percent respondent are 
disagree with this factors. Regarding Skilled labour factor, 60 percent respondent supported this factor. More than 40 percent respondent supported business climate and Specific Sector Performance factors whereas 16.66 respondents are disagree with labour law factor.

\section{Table 7.1}

\section{Analyse of table 7}

\begin{tabular}{|l|l|l|l|}
\hline S.no & Factor & Mean Score & Rank \\
\hline 1. & $\begin{array}{l}\text { Business } \\
\text { Climate }\end{array}$ & 4.33 & 2 \\
\hline 2. & $\begin{array}{l}\text { Political } \\
\text { Stability }\end{array}$ & 4.33 & 2 \\
\hline 3. & Labour Laws & 2.9 & 7 \\
\hline 4. & Skilled Labour & 4.26 & 3 \\
\hline 5. & India's Image & 4.13 & 5 \\
\hline 6. & Infrastructure & 4.16 & 4 \\
\hline 7. & $\begin{array}{l}\text { Economic } \\
\text { reforms }\end{array}$ & 3.93 & 6 \\
\hline 8. & Entry Options & 4.56 & 1 \\
\hline 9. & Exit Options & 4.56 & 1 \\
\hline 10. & $\begin{array}{l}\text { Specific Sector } \\
\text { Performance }\end{array}$ & 4.33 & 2 \\
\hline
\end{tabular}

Source: Primary Data

Interpretation: From the ranking method of the mean score in the above table 5.1, ten parameters have been identified which impact the investment strategies of institutional investor in India .Among the various parameters, Entry and exit options are identified most important factors which impact the investment strategy of institutional investor in India. Next important parameters which are ranked at two are Political Stability and Business Climate .Other important factors identified according to the survey are Skilled Labour, Infrastructure, India's image, Economic reforms and Labour laws.

\section{FINDING}

A favourable entry and exits option investment strategy is vital for the development of institutional investors. Good political stability and business environment is also desirable for investors of any government .Unstable economic environment could create difficulties for attracting and growing institutional investments. Government should adjust their agenda accordingly and be more prudent in launching major initiatives. Institutions that have accessed the capital markets to fulfil their financing needs should have clear objectives of schemes,transparent, timely and complete disclosure of material information .Proper corporate governance will promote a transparent and efficient market and increase investor's confidence. Government should lower the explicit transaction costs such as taxes, fees and transaction commission; this will increase market participation of the institutional investor. Financial instruments that are less followed by analysts and investors as per our survey (National Saving Certificate and Pubic Provident Funds) are thinly traded. It is very difficult for institutional investor to buy and sell such instruments with meaningful size. Introducing market making mechanism would narrow the bid/ask spread and make large volume transaction possible for institutional investors.

\section{CONCLUSION:}

Portfolio approach provides investor with a way to reduce the risk associate with their investment without necessarily decreasing their expected return .The risk can be minimized with the help of diversification .Therefore investors come up with a portfolio in which they make an investment into different sector that are not related to each other (Joseph and Varghese , 2017).The investor can build various type of portfolio depending on the risk - taking capability. They give importance to the assets or the sector based on their investment strategy. While taking the investment decision preference should be given to economic, political, business and legal conditions (Jault, 2015).The institutional investors play a very important role in the investment decision .They make long -term commitment to the organization and do diversified investment .They drive the market because they make an investment in bulk (Johannes ,2017). They are trusted by the investors because of their expertise. In the last few tears, the investment by the Foreign Institutional investor (FIIs) and Domestic Institutional investors (DIIs) have grown .This is a positive sign of the economic conditions (Agarwal, 2016).

\section{REFERENCE:}

[1]. Agarwal, B. (2016).FII Inflows into Indian IPOs and its impact on the Indian Stock Market

[2]. Bland, J .M., \& Altman, D.G. (1997) .Statistics notes: Cronbach's Alpha .B (7080), 572.

[3]. 3.Bushee, B.J., Carter, M.E. \& Gerakos, J., 2014 .Institutional Investor Preferences for Corporate Governance Mechanisms .Journal of Management Accounting Research ,26 (2) ,pp.123149.

[4]. Fachrudin, K.A., \& Fachrudin, H.T. (2015) .The Study of Investment Portfolio Management and Sustainability of Property and Real Estate Companies in Indonesia Stock Exchange .Procedia-Social and Behavioural Sciences, 211,117183.

[5]. Hutchinson, M., Seamer, M. \& Chapple, L (Ellie) .2015 .Institutional Investors, Risk/Performance and Corporate Governance .The international Journal of Accounting, 50(1), pp.31-52.

[6]. Isaksson, M. \& Celik, S., 2014 .Institutional investors and Owner Engagement .OECD JOURNAL: Financial Market Trend, 2013, pp.93-114.

[7]. Johannes, R.L.(2017) .U.S. Patent Application No .15/369,486. https://patents.google.com/patent/US20170213284A1/en.

[8]. Joseph, A., \&Varghese, J. (2017). A Study on Factors Affecting Investment Decision Making in the context of Portfolio Management.

[9]. Jault, J.B. (2015) .Investment Portfolio Management.

[10].Koh,P.-S.,2007.Institutional Investor type ,earnings management and benchmarks beaters .Journal of Accounting and Public policy, 26(3) ,pp.267-99.

[11]. Keloharju (2000). The Investment behaviour and performance of various investor type: A study of Finland's unique data set Journal of Financial Economics, Vol.55, Issue 1, 43-67.

[12].Luo, Y., 2002.Contract, cooperation and performance in international joint ventures. Strategic Management Journal, 23(10), pp. 903-919.Avaialble

at 
http://doi.wiley.com/10.1002/smj.261

[13].Nielsen, K.M., 2008.Instiutional Investors and Private Equity Review of Finance, 12(1), pp.185-219.

[14].Nicole Choi et.al, 2017. Portfolio Concentration and performance of institutional investor worldwide. Journal of financial economics, Vol.123 (1), pp.189-208.

[15].OECD, 2011.The Role of Institutional Investors in Promoting Good Corporate Governance .OECD Reports 25November 2011, 61, p.299.

[16].Priyanka Sharma and Payal Agarwal (2015). "Investor Perception and Attitude towards Mutual Fund as an Investment option" .Journal of Business Management \& Social Science Research (JBM\&\$\$).Volume 4, No.2, pp: 115-119s

[17].RaviVyas, Suresh Chandra Moonat (2012). Perception and Behaviour of Mutual Funds Investors in Indore, Madhya Pradesh. Indian Journal of Finance .Volume 6, Issue8 .

[18].Sarkar, J. \& Sarkar, S., 2000.Large Shareholder Activism in Corporate Governance in Developing Countries: Evidence from India .International Review of Finance, 1(3), pp.161-194.

[19]. Sudalaimuthu, s.and Senthil Kumar, P., (2008). "A Study on investors perception towards mutual fund investments." Journal of Management Trends, Volume 1.5(1), September 2007March 2008, pp.106-17

[20]. Gopikumar, Smitha Nair, S Sreevathsava \& Raja Sreedharan V, David McMillan (Reviewing editor :) (2019) Financial Strength Information and Institutional Investor Demand: Evidence from India, Cogent Economics \& Finance.DOI:10.1080/23322039.2019.1623751.

\section{AUTHOR DETAILS}

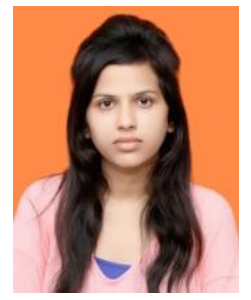

Shivani Tyagi ,UGC NET JRF QUAILIFED ,Senior Research Fellow, Amity University .Noida .Academic Area: Portfolio Management ,Equity Publication :8

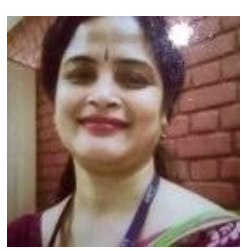

Dr. Manjula Shastri, Associate Professor .Amity University .Noida .Academic Area: Accounting and Finance. Publication:20 